\title{
Outline of the Nagssugtoqidian mobile belt of East Greenland
}

\author{
David Bridgwater and John S. Myers
}

\begin{abstract}
The Nagssugtoqidian mobile belt is a $240 \mathrm{~km}$ wide zone of deformation and plutonic activity which cuts across the Archaean craton of East Greenland. The belt was established $2600 \mathrm{~m}$.y. ago by the formation of vertical E-W shear zones and the syntectonic intrusion of basic dykes. Tectonic activity along the $\mathrm{E}-\mathrm{W}$ shear zones was followed by the emplacement of tonalitic intrusions, the Blokken gneisses, $2350 \mathrm{~m}$.y. ago in the central parts of the mobile belt. The emplacement of the Blokken gneisses was accompanied and followed by further emplacement of basic dykes. These are synplutonic in the centre of the mobile belt but are emplaced into more rigid crust in the marginal areas of the belt and in the Archaean craton to the north and south. During a second major tectonic and thermal episode circa 1900 m.y. ago, the region was deformed by thrusting from the north. In the southern part of the mobile belt the earlier steep shear zones are cut by shear zones dipping gently northwards in which rocks are downgraded to greenschist facies. The grade of metamorphism increases northwards and shear zones are replaced by open folds with axial surfaces which dip gently northwards. The increasing ductility in the centre of and northern part of the belt is associated with the intrusion of charnockitic plutons and their granulite facies aureoles. Regional uplift occurred before the intrusion of high level post-tectonic plutons of diorite and granite 1550 m.y. ago.
\end{abstract}

\section{Introduction}

The Nagssugtoqidian mobile belt of East Greenland forms a well defined structural province centred about Angmagssalik (fig. 1) and extending for $240 \mathrm{~km}$ across strike (Bridgwater, 1976, Bridgwater et al., 1977, 1978). We estimate that at least 90 per cent of the rocks within the mobile belt are Archaean gneisses and supracrustal rocks which have been affected by later tectonic and metamorphic processes; the remaining 10 per cent consisting of relatively restricted amounts of Proterozoic basic dykes and syn- to post tectonic intrusions. The formation of younger sialic magmas is concentrated within a $100 \mathrm{~km}$ zone in the centre of the mobile belt. Compared to the Archaean gneiss complexes to the north and south the Nagssugtoqidian mobile belt contains a relatively high proportion of Archaean supracrustal rocks dominated by pelitic and semipelitic sediments with minor quartzites, calcareous units, thin ironstones, and amphibolites. This is comparable to the increase in supracrustal rocks seen in the Nagssugtoqidian of West Greenland. The supracrustals are associated with calcic anorthosites and ultramafic lenses resembling the igneous suites seen for example in the Fiskenæsset district of West Greenland (Myers, 1975). The Archaean rocks north of the mobile belt are largely in granulite facies, they have yielded a $\mathrm{Pb}-\mathrm{Pb}$ whole-rock age of circa 2750 m.y. (Taylor in Bridgwater et al., 1976). South of the 

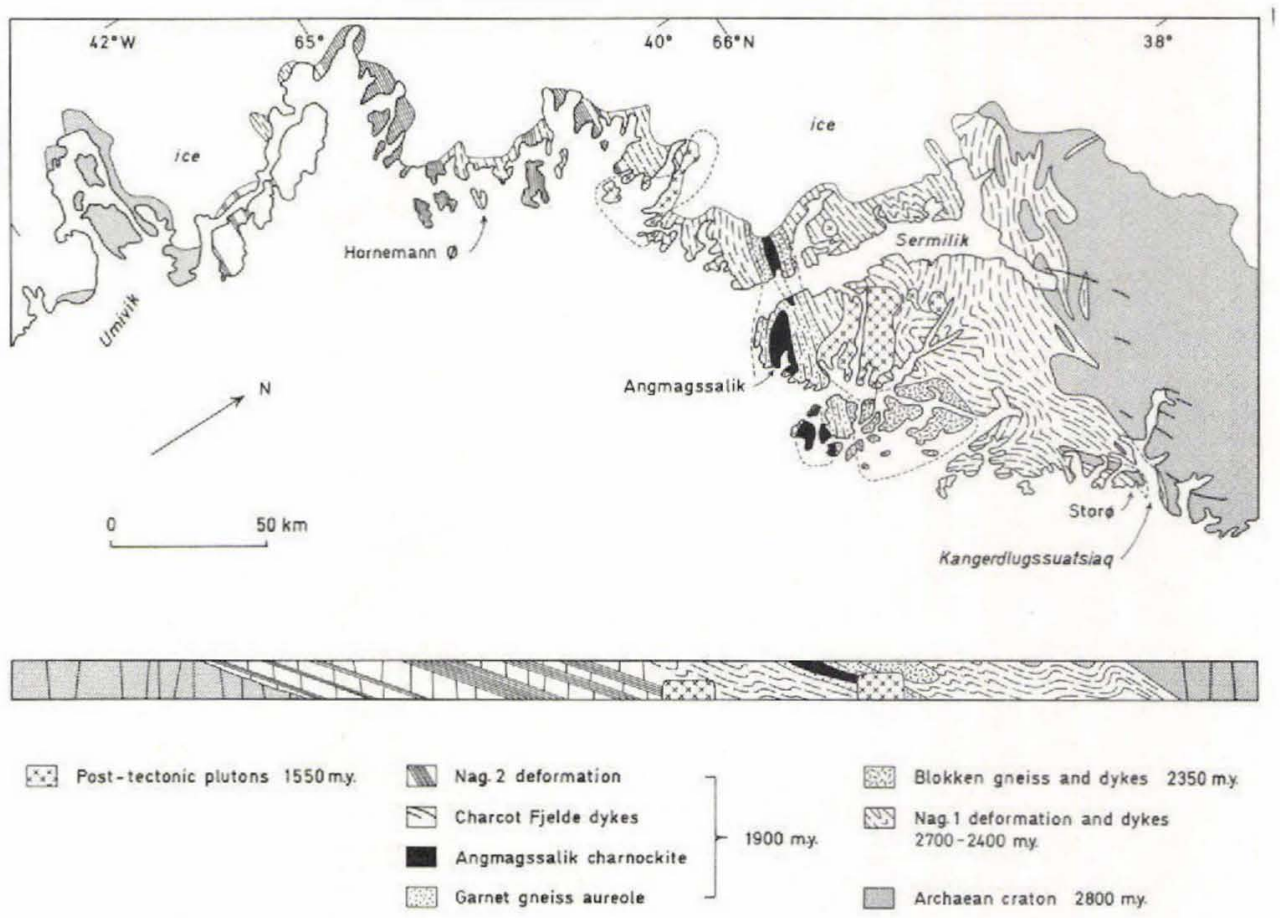

Fig. 1. Generalised map and section of the Nagssugtoqidian mobile belt, South-East Greenland.

mobile belt most of the Archaean gneisses are in amphibolite facies. U-Pb determinations on zircons from an anorthosite lens from within the mobile belt gave an age of 2700 m.y. (Nunes et al., 1974) interpreted by us as the age of migmatisation of the anorthosites.

\section{Nag. 1 deformation}

The earliest structures regarded as forming an integral part of the mobile belt (Nag. 1) are vertical E-W belts of high deformation which cross-cut earlier fold structures in the Archaean gneisses. Samples from one shear zone and its country rocks have yielded a $\mathrm{Rb}-\mathrm{Sr}$ whole-rock age of $2635 \pm 55$ m.y. (Bridgwater et al., 1978).

The vertical shear zones correspond to isolated shear zones in the Archaean gneisses to the north and south, but are much more numerous within the mobile belt where they control later tectonism and magmatism. Maximum extension within the vertical shear zones is sub-horizontal and the movements are transcurrent.

The main northern boundary of the Nagssugtoqidian at the mouth of Kangerdlugssuatsiaq is well defined by an E-W steeply dipping belt of high deformation. North of this boundary the Archaean basement rocks are little affected by Nagssugtoqidian movements except for local well-defined narrow shear belts and fractures.

Near the northern boundary of the mobile belt the E-W shear zones are seen to be 
associated with networks of pale gneiss formed during partial retrogression of the Archaean granulite facies rocks. Deformation and recrystallisation within the shear zones was accompanied by marked changes in the composition and distribution of the feldspathic components in the gneisses. Andesine with antiperthite blebs of $\mathbf{K}$-feldspar breaks down to oligoclase and frees potash feldspar. Magnetite with ilmenite lamellae becomes unstable and hydrated ferrous oxides form. Scapolite and muscovite become rock-forming minerals in the centres of the shear zones. The structural and mineralogical changes are accompanied and controlled by marked changes in chemistry with considerable introduction of $\mathrm{K}, \mathrm{Rb}, \mathrm{Cl}, \mathrm{Ba}$ and probably $\mathrm{Si}$ and the oxidation of sulphide to sulphate in the shear zones compared to their immediate country rocks. $\mathrm{Na}, \mathrm{Ca}$ and $\mathrm{Zr}$ are apparently lost from the shear zones at the present erosion level. $\mathrm{Fe}$ (tot), $\mathrm{Mg}$, $\mathrm{Ti}, \mathrm{Sr}$ and $\mathrm{Al}$ appear unchanged. Comparison between the shear zones and the completely unmodified granulite facies is more speculative because of difficulties in being certain that the two populations of rocks sampled represent the same starting material. The present results suggest that at least for $K$ and $R b$ the shear zones represent the most extreme results of a general metasomatism which occurred on a regional scale during retrogression of granulite facies gneisses. We interpret the $2635 \mathrm{~m}$.y. Rb-Sr age obtained from the shear zones and their country rocks as close to the age of Rb addition during retrogression. Both $\mathrm{U}$ and $\mathrm{Pb}$ were added to the gneisses during retrogression and it is therefore hoped to obtain a more precise age of metasomatism in the shear zones using $\mathrm{U}-\mathrm{Pb}$ determination on zircons.

\section{Basic dykes}

Within the area mapped as the Nagssugtoqidian mobile belt there is a great abundance of basic dykes. These correspond both in chemical character and in many details of their intrusion mechanics to the widespread Proterozoic dyke swarms of the North Atlantic region extending from the Norwegian coast through NW Scotland to West Greenland and Labrador (Escher et al., 1976). There is good field evidence from East Greenland that the dykes within the Nagssugtoqidian mobile belt belong to several generations separated by tectonic events (Bridgwater et al., 1973). We suggest that the dykes range in age from the 'age' of the E-W shear belts at about $2600 \mathrm{~m}$.y. through to the age estimated for the second main period of tectonic movement in the mobile belt at about 1900 m.y. Parts of the swarm thus may correlate with the circa 2400 m.y. Scourie dykes of mainland NW Scotland, other parts with the Kangâmiut dykes of West Greenland dated at 1950 m.y. (Kalsbeek et al., 1978).

The dykes within the area affected by the Nagssugtoqidian deformation show many features which differ from dykes emplaced into cold stable crust as seen for example in the Archaean craton to the south.

The dykes show a marked increase in volume in the areas affected by Nagssugtoqidian tectonism. Their primary intrusion forms are clearly related to movements within the dyke fissures. South of the mobile belt dykes of comparable age are rectilinear dolerites emplaced into a crust which was apparently stable at the present erosion level. North of the tectonic boundary of the mobile belt the dykes, although sometimes very wide, are considerably less abundant. Some show intrusion forms and mineral assemblages suggesting that the country rocks in this area may have been plastic at the time of dyke intrusion possibly indicating that 


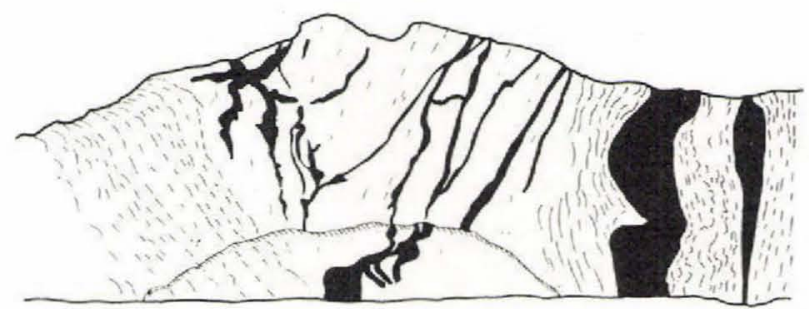

a

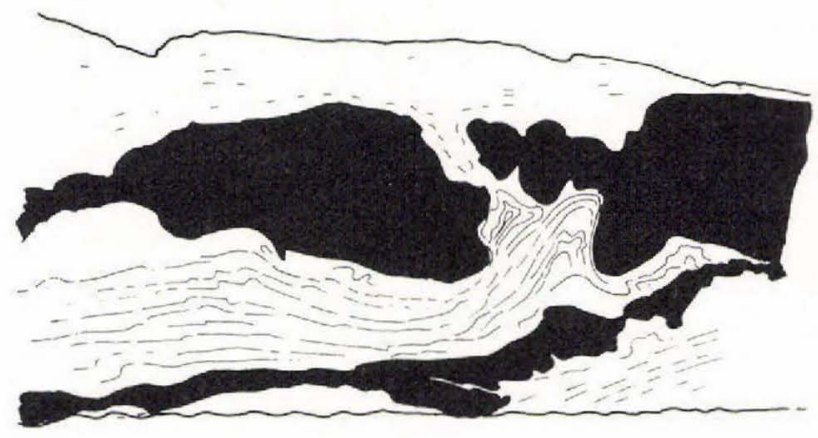

b

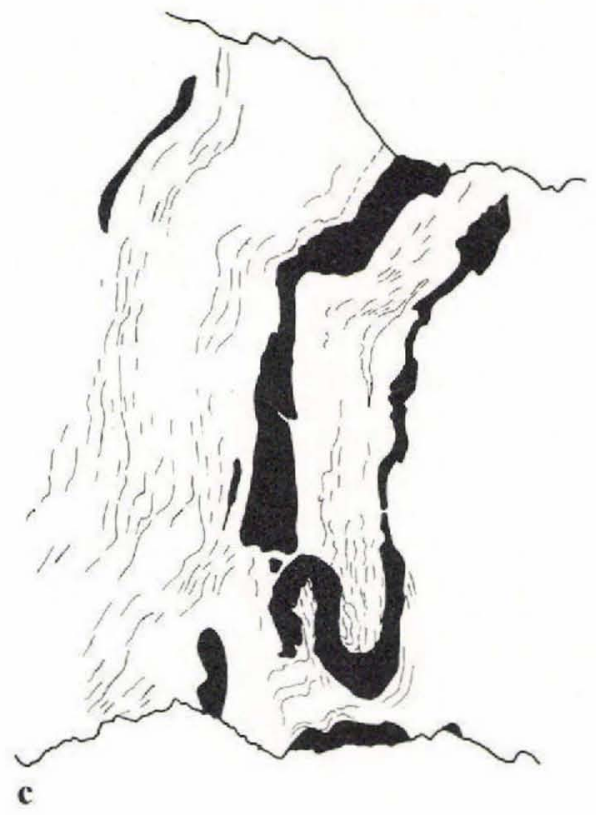

Fig. 2. Primary intrusion forms of basic dykes found within the Nagssugtoqidian. (a) East end of Hornemann $\varnothing$. Cliff face approximately $250 \mathrm{~m}$ high. Note the branching network of irregular bodies in the centre of the sketch. The country rocks here consist of massive Archaean amphibolite facies gneisses. These are flanked to the right and left by gneisses affected by a strong post-Archaean shearing. The dykes in the strongly foliated gneisses are intruded parallel to the shearing and show primary podded forms. The dykes from this part of the mobile belt vary between noritic bodies with little sign of recrystallisation to composite garnet amphibolites with quartz diorite centres. (b) Podded garnet-orthopyroxene bearing dyke with primary ophitic textures and amphibolitic margins and apophyses in a shear zone on Storø. The section is approximately $80 \mathrm{~m}$ high. (c) Irregular garnet amphibolite dyke emplaced approximately along the contact between Archaean tonalitic gneisses and earlier metasediments $\quad 66^{\circ} 03^{\prime} \mathrm{N}$, $35^{\circ} 55^{\prime} \mathrm{W}$. The dyke is subconcordant to the foliation in the gneisses. The section shown is approximately $300 \mathrm{~m}$ high. 
the present section represents a very deep level in the crust. Within the belt, intrusion forms are closely related to the tectonic fabric of the surrounding country rocks. Dykes emplaced into active shear zones form strings of pods within the deformed rocks, dykes emplaced into massive country rocks are frequently highly irregular with many apophyses and sudden changes in direction both in a vertical and horizontal section (fig. 2).

Chemically the dykes within the mobile belt can be subdivided into two groups corresponding closely to the dykes in the Archaean craton further south. (1) A group of norites with relatively high $\mathrm{SiO}_{2}$ contents, high $\mathrm{Mg} / \mathrm{Mg}+\mathrm{Fe}$ ratios and high $\mathrm{Cr}$ and $\mathrm{Ni}$ contents. The least metamorphosed of these are indistinguishable from the early hypersthene-bearing dykes described by Berthelsen \& Bridgwater (1960) from West Greenland. These have only been noted south of Sermilik. They commonly retain their primary igneous mineralogy with hypersthene, olivine, clinopyroxene and clouded plagioclase even towards the centre of the mobile belt. Intersections with other dykes show that the norites are early in the sequence of events. (2) Fe-tholeiites probably of many different generations. These correspond in chemistry to the Kangâmiut dykes of West Greenland and the younger dolerites cutting the Archaean block to the south. Some of these dykes are composite, with quartz diorite centres comparable to the composite dykes described by Bridgwater et al. (1976) and Kalsbeek et al. (1978). Although this group includes the youngest dykes in the swarm they rarely contain indisputable primary igneous assemblages and even in the Archaean block for some $50 \mathrm{~km}$ south of the mapped boundary of the mobile belt are generally hornblende-bearing and may be slightly schistose. Within the mobile belt many of these dykes have schistose amphibolitic margins and garnet-bearing centres with ophitic or sub-ophitic textures still preserved.

\section{Blokken gneisses}

Formation of the E-W shear belts was followed in the central part of the belt by the emplacement of calc-alkaline magma (diorite, tonalites and granodiorites, the Blokken gneisses). These are distinguished in the field from the surrounding Archaean tonalites by the common preservation of primary igneous textures and by the lack of evidence that they were affected by an early granulite facies event. They give a whole rock age of approximately $2350 \mathrm{~m} . y$. (Taylor in Bridgwater et al., 1978). The Blokken gneisses contain broken up sinuous basic dykes interpreted as emplaced into partially mobile country rock. Other major metadolerites intrude the Blokken gneisses with no sign of country rock mobility.

The full extent of the Blokken gneisses is not known and may prove very difficult to map since when deformed by younger tectonic events they closely resemble the Archaean gneisses. They have only been identified in the area to the north-east of Angmagssalik that is close to the centre of the mobile belt. Internal relationships between mafic and less mafic phases suggest that the Blokken gneisses were emplaced under syntectonic conditions. They are the only known major bodies of sialic plutonic rock of this age in the North Atlantic region.

\section{Angmagssalik charnockite complex}

The Archaean gneisses were intruded by one or more sub-concordant igneous sheets the major rocks types of which range from andesine leuconorites through to quartz mangerites and charnockites. Primary intrusive contacts are well preserved. They outcrop between the 
western shores of Sermilik eastwards through Angmagssalik (fig. 1). They commonly weather to a gravel rubble and are comparatively poorly exposed in the inland areas. They are not seen to be intruded by meta-basic dykes although remnants of these occur in the immediate country rocks and in the inclusions within the igneous complex, and we therefore place the basic charnockite suite (Wager, 1934) late in the sequence of events in the area. Primary igneous features are preserved in the centre of the sheets although the complex has been folded by younger Nagssugtoqidian movements. The country rocks surrounding the complex are almost completely recrystallised for several kilometres away from the contact and contain granulite facies mineralogy. We regard the charnockites as deep-seated intrusions emplaced just before or possibly during the youngest phase of Nagssugtoqidian deformation. We have not seen any evidence that they represent lower crustal material emplaced tectonically into the gneiss complex as postulated by Moorlock et al. (1972).

The charnockite complex is surrounded by a wide envelope of garnet granitic gneisses (Wager, 1934). These contain all the lithological elements recognised from the Archaean gneiss complex ranging from anorthositic fragments through tonalitic grey gneisses to pelitic metasediments and calcareous units. These retain their relative stratigraphic positions on a regional mapping scale but are almost completely broken up and recrystallised on the scale of individual outcrops so that the garnet gneisses frequently have the appearance of a vast melange. Locally parts of the garnet gneisses have become mobile and intrusive sheets occur with remelted garnet granites cutting through older structures carrying blocks of 'country rock' with them. Parts of the garnet gneisses are cut by networks of thin ultramafic veins consisting largely of hypersthene, biotite and garnet sometimes concentrated in pipe-like bodies with rounded inclusions of gneiss and metasediment within them.

The degree of recrystallisation shown by the garnet gneisses increases as the margins of the charnockite sheets are approached and we therefore assume that the formation of garnet gneisses and the intrusion of the charnockites are closely related in time.

\section{Nag. 2 deformation}

The second major phase of deformation within the Nagssugtoqidian mobile belt (Nag. 2) in East Greenland occurred after the intrusion of the majority of basic dykes in the area. It is thought to have been controlled by compressional movements during which Archaean rocks from the north and north-west were thrust over the area affected by the earlier E-W shear belts and the Archaean block to the south. Both in general character and in timing within the local sequence of events this phase of deformation corresponds to the later structures within the Nagssugtoqidian mobile belt of the west coast (the Nag. II of Watterson, 1974, and the Nagssugtoqidian 'orogeny' of Kalsbeek, this volume). Rb-Sr whole rock studies from both the garnet gneisses (described above) and from highly deformed Archaean gneisses from the centre of the mobile belt have both yielded scattered points about a 1900 m.y. isochron. We suggest it is a reasonable estimate for the age of partial equilibration of the $\mathrm{Rb}-\mathrm{Sr}$ whole-rock systems during high grade metamorphism associated with the Nag. 2 tectonic event.

The character of the younger deformation in the Nagssugtoqidian mobile belt changes markedly across the strike (Bridgwater \& Gormsen, 1968; Bridgwater, 1976; Bridgwater et al., 1978) reflecting at least in part the erosion section now seen. At the southern margin of 
the belt $\left(64^{\circ} 20^{\prime} \mathrm{N}\right)$ the structures appear as low-dipping sharply defined shear zones of highly deformed rocks tens of metres wide with marked linear fabrics plunging within the shear planes at $20^{\circ}-30^{\circ}$ to the north and north-west. Imbricate structures are common. The boundaries between deformed and undeformed material are sharp. Typical dykes in the border zone of the mobile belt are $10-50 \mathrm{~m}$ wide fresh dolerites up to the shear zones thinning to $1+2 \mathrm{~m}$ amphibolites within the shears. Textures of the gneisses within the shear zones become mylonitic. There is copious epidote and chlorite suggesting that the present level of erosion represents a high level in the Proterozoic crust.

Further north $\left(65^{\circ}-65^{\circ} 30^{\prime}\right)$ the shear zones become broader and their margins more diffuse. Amphibolite facies minerals including kyanite develop parallel to the main extension directions. Large post-dyke pegmatites become numerous. The original form of the basic dykes pre-dating the low-angle shear movements is more irregular, possibly reflecting a deeper level of erosion or higher heat flow in the area. In areas little affected by the late deformation, primary igneous mineralogy is preserved in some dykes as far north as the mouth of Sermilik $\left(65^{\circ} 35^{\prime}\right)$.

Between $65^{\circ} 30^{\prime} \mathrm{N}$ and the northern margin of the mobile belt at $66^{\circ} 20^{\prime}$ the mobile belt is characterised by complex interference patterns between earlier dominantly vertical structures and the late deformation resulting in spectacular eye fold structures. Metamorphic conditions during the late Nagssugtoqidian in the area north of $66^{\circ} 30^{\prime}$ varies between high amphibolite and granulite facies. Sillimanite overgrowths form on kyanite in the pelitic rocks possibly as a reaction to gradually falling pressure.

\section{Post-tectonic plutons}

The final event in the Nagssugtoqidian belt was the intrusion of the post-tectonic plutons ranging from rare ultrabasic masses to basic diorites, quartz diorites and potash granites. $\mathrm{Rb}$-Sr age determinations (Bridgwater et al., 1978; P. Taylor, unpublished) range between 1550 and 1580 m.y. The intrusions are concentrated in the central part of the belt which had previously been affected by Proterozoic high grade metamorphism.

The late granitic suite ranges from hornblende and pyroxene-rich rocks with basaltic compositions and occasional ultramafic cumulates through to quartz monzonites and mafic-poor granites. In individual intrusions there is a progression from basic to acid, commonly with basic inclusions in intermediate rocks and intermediate inclusions in acid rocks. The intrusions show a gradual increase in the amount of granitic material, the youngest bodies being porphyritic granites sometimes with rapakivi textures. Relationships between acid and basic parts of the intrusions are complex, net-veined bodies, granite-pipes in basic rocks, pillowed dykes and local hybridisation are common. Stoped blocks and roof pendants are common in the upper parts of the intrusions. Chemically the late intrusions follow normal calc-alkaline trends. Several of the intermediate rocks are extremely high in $\mathrm{Ba}$ and $\mathrm{Zr}$ with values exceeding 7000 and $1000 \mathrm{ppm}$ respectively.

The genetic relationships between acid and basic parts of the complexes is uncertain. The Sr initial ratio of 0.7035 obtained on one pluton (Pedersen in Bridgwater $e t$ al., 1978) gives no clear evidence of the source of the acid material since the average $\mathrm{Rb} / \mathrm{Sr}$ ratio of the Archaean crust in this area is so low that initial ratios of crustal derived granites or contamination by crustal material would not be easily seen by this method. Volumetric considera- 


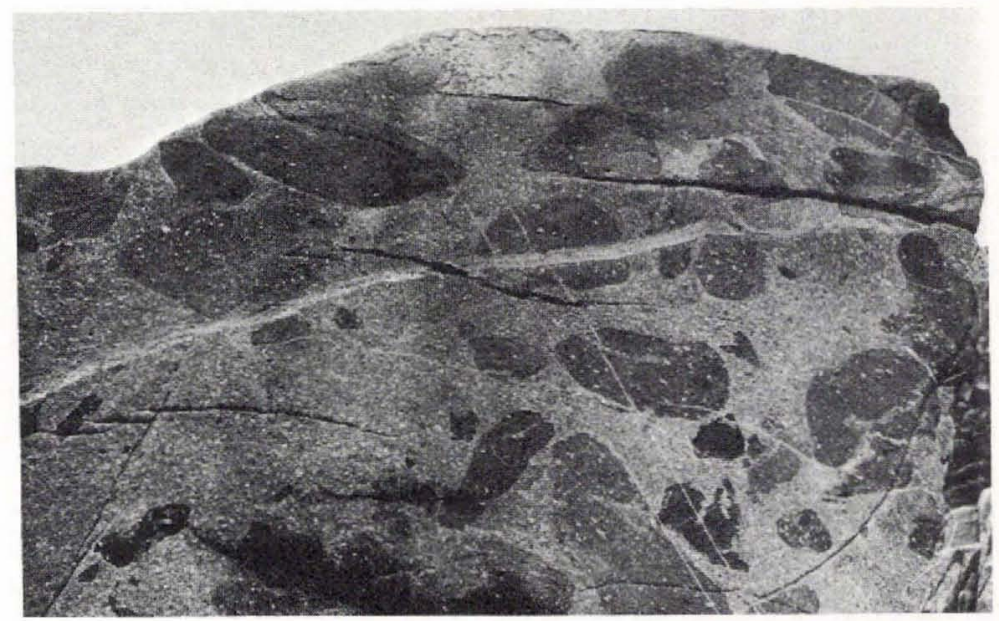

Fig. 3. Acid-basic relations in the post-tectonic granites. Angmagssalik $\varnothing$.

tions rule out crystal fractionation in place as the main process controlling the present relationships. Local evidence of contemporaneous acid and basic magmatism (net-veining and pillows of basic rocks in acid material) suggests that some of the intermediate rocks could be mixtures of two distinct end members. Available trace element data does not lie on straight mixing-lines and we regard hybridisation as only locally important. Our preferred interpretation at present is that the granitic members of the suite represent either partially remelted earlier basic phases emplaced at depth or is older sial remelted by basic magmas. We suggest that the remelting may be triggered by continuous emplacement of basic material at a lower level in the crust represented at higher levels by the pillowed basic dykes and net-veined bodies.

\section{Conclusions}

The tectonic and magmatic activity in the Nagssugtoqidian continued after the close of Archaean high grade metamorphism for approximately $1000 \mathrm{~m} . \mathrm{y}$. Available age determinations suggest that there may have been two major peaks of thermal activity at about 2600 m.y. and between 1900 and 1500 m.y. ago corresponding to the two main phases of deformation recorded. However, there is both isotopic and field evidence that within the mobile belt the two phases of thermal activity were not separated by a period of crustal stability but were part of a more continuous series of events. The tectonic, metamorphic and magmatic activity between $1900 \mathrm{~m} . \mathrm{y}$. and $1500 \mathrm{~m} . \mathrm{y}$. occurred within a restricted area the boundaries of which were already defined at $2600 \mathrm{~m}$.y. and which had been the locus for dyke injection, shearing, and some plutonic activity, in the intervening period. In this review we have therefore deliberately emphasised the idea that the term Nagssugtoqidian is best applied to a restricted geographical area affected by a distinct series of tectonic, magmatic and metamorphic events which together make up a structural province. The usage corresponds closely to 
other areas in which there has been repeated tectonic and thermal activity over an extended time interval, for example the Limpopo mobile belt (Coward et al., 1976) with which the Nagssuqtoqidian mobile belt has many features in common. We prefer this usage to that of a pure time division (Kalsbeek, 1979) since we feel that major divisions on a map should reflect features which are observable on the ground. A map showing rocks which post-date a particular pair of dated dykes on the west coast (and pre-date other undefined criteria) would firstly only show very few rocks as 'Nagssugtoqidian' and secondly could only be made properly after each unit had been dated reliably. A regional tectonic usage, such as we prefer, shows major divisions corresponding to field observations and does away with endless discussion about whether dykes emplaced during active tectonism within the mobile belt correspond exactly in time with dykes emplaced under different crustal conditions tens or hundreds of kilometres away.

\section{References}

Bridgwater, D. 1976: Nagssugtoqidian mobile belt in East Greenland. In Escher, A. \& Watt, W. S. (edit.) Geology of Greenland, 97-103. Copenhagen: Geological Survey of Greenland.

Bridgwater, D., Davies, F. B., Gill, R. C. O., Gorman, B. E., Henriksen, N. \& Watterson, J. 1977: Field mapping in the Nagssugtoqidian of South-East Greenland. Rapp. Grønlands geol. Unders. 85, 74-83.

Bridgwater, D., Davies, F. B., Gill, R. C. O., Gorman, B. E., Myers, J. S., Pedersen, S. \& Taylor, P. 1978: Precambrian and Tertiary geology between Kangerdlugssuaq and Angmagssalik, south-eastern Greenland. Rapp. Grønlands geol. Unders. 83, 17 pp.

Bridgwater, D., Escher, A. \& Watterson, J. 1973: Dyke swarms and the persistence of major geological boundaries in Greenland. In Park, R. G. \& Tarney, J. (edit.) The Early Precambrian of Scotland and related rocks of Greenland, 137-141. University of Keele.

Bridgwater, D. \& Gormsen, K. 1969: Geological reconnaissance of the Precambrian rocks of south-east Greenland. Rapp. Grønlands geol. Unders. 19, 43-50.

Coward, M. P., James, P. R. \& Wright, L. 1976: Northern margin of the Limpopo mobile belt, southern Africa. Bull. geol. Soc. Amer. 87, 601-611.

Escher, A., Jack, S. \& Watterson, J. 1976: Tectonics of the North Atlantic Proterozoic dyke swarm. Phil. Trans. Roy. Soc. Lond. A, 280, 529-539.

Kalsbeek, F. 1979: Rb-Sr evidence on the age of the Nagssugtoqidian orogeny in West Greenland, with remarks on the use of the term 'Nagssugtoqidian'. Rapp. Grønlands geol. Unders. 89 (this volume).

Kalsbeek, F., Bridgwater, D. \& Zeck, H. P. 1978: A $1950 \pm 60$ Ma Rb-Sr whole-rock isochron age from two Kangâmiut dykes and the timing of the Nagssugtoqidian (Hudsonian) orogeny in West Greenland. Can. J. Earth Sci. 15, 1122-1128.

Moorlock, B. S. P., Tarney, J. \& Wright, A. E. 1972: K-Rb ratios of intrusive anorthosite veins from Angmagssalik, East Greenland. Earth Planet. Sci. Lett. 14, 39-46.

Myers, J. S. 1975: Igneous stratigraphy of Archaean anorthosite at Majorqap qâva, near Fiskenæsset, South-West Greenland. Rapp. Grønlands geol. Unders. 74, 1-27.

Nunes, P. D., Steiger, R. H. \& Bridgwater, D. 1974: A zircon age from gabbro-anorthosite inclusions in the gneisses of the Angmagssalik area, South-East Greenland. Rapp. Gronlands geol. Unders. 66, 21-31.

Wager, L. R. 1934: Geological investigations in east Greenland. I. General geology from Angmagsalik to Kap Dalton. Meddr Grønland 105 (2), 46 pp. 
Watterson, J. 1974: Investigations on the Nagssugtoqidian boundary in the Holsteinsborg district, central West Greenland. Rapp. Grønlands geol. Unders. 65, 33-37.

Geological Survey of Greenland,

Øster Voldgade 10,

DK-1350 Copenhagen $\mathrm{K}$,

Denmark. 